鉛被覆の上にさらにアルミ被覆を施せば，継手強さを 向上させることがわかった。このように適切な方法で アルゴンアーク溶接を行なえば $30 \mathrm{~kg} / \mathrm{cm}^{2}$ に達する継 手強さがえられる。 [妹島 五彦]

$621.776: 621.983$

※[733] 冷間望性加工の最近の進歩 [H.Ll. D. Pugh, Chart. Mech. Engr., 1966-4, Vol. 13, No. 4, p. 156 162, 図 9] 最近一般需要とくに宇宙開発や原 子力関係の要求から泠間加工製品の生産量が急速にふ えつつある，中でも注目されている鋼の冷間押出し， 高速加工，液体押出しについて特徵と工業的応用につ いて述べている．液体押出しは一様なひずみとき裂防 止に従来のラム押出しでは得られない特徵を示しドリ ルの製作や電線の押出し工程に利用される. 押出しに 必要な油圧 $p$ は押出し比 $R$ とビレットのビッカース かたさ $H$ の関数でダイ角度 $45^{\circ}, H_{V}=8 \sim 440$ の場合 に $p=\ln R(0.375 H+4)$ で示される．被覆電線の製 造とか従来の押出し加工ではき裂のはいるもるい試料 の加工には，この液体押出しが非常に有効に利用され ている．高速加工には爆発成形加工，衝撃ハンマによ る加工（ダイナパック），電磁加工などがあり管の一 部をふくらせたりべローをつくったり薄板の押出し加 工を行なうのに有効である．鋼の冷間押出しについて は $p=H^{0.72} \cdot 2.8(\ln R)^{0.72}$ の押出し圧力が得られてい て, ダイの角度によって変わるが将来は捧, 管, コッ プ風のものの加工に現在よりも大量に使用される予定 である。

[中井靖]

\section{$539.62: 539.374$}

[734] 巨視的変形の下における摩擦係数の決定法 [A.T. Male \& M.G. Cockcroft, J. Inst. Metals, 1964/1965, Vol. 93, p. 38 46, 図 14, 表 3] 平 らなリング状試料を圧縮してその寸法変化から，剛体 工具と塑性変形している金属間の摩擦係数を決める方 法を述べ，その方法は試料温度，変形量，変形速度， 潤滑など広範囲の試験条件のもとでも適用できること を明らかにした論文である．すでにリングの圧縮につ いては久能木の研究があるが, 著者は 0.75 in 外径, 0.375 in 内径, 0.25 in 高さの標準試験を使って圧縮 した後の内径変化率 $\Delta D(\%)$ と変形量の関係を求め, つぎに同一材，同一条件下で円板の圧縮を行なって Shroeder と Webster の解析を利用して $\mu$ を計算し, $\mu$ と $\Delta D$ の関係を求めた. 標準試料に対し $\Delta D=m$ ln ( $\mu / 0.055)$, ただし $\ln m=(0.044 \times$ 変形量 $\%)+10.6$ の実験式を求めて， $\Delta D$ の測定によって $\mu$ を決定して いる.この方法は材料の機械的性質によらず，非常に 敏感な利点はあるが，バルジ現象や中性面半径の変化 や不均一変形など複雑な過程が内在するから，大きな 変形量では若干の誤差が生ずる久点があるが, 塑性加 工の限られたデータではよい一致が得られる.

\section{[葉山 益次郎]}

\section{$539.62: 539.374$}

[735] 塑性加工時の摩擦挙動に対する温度の影響

[A.T. Male, J. Inst. Metals, 1964/1965, Vol. 93, p. 489 494, 図 2,·表 2]無潤滑状態における種々 の金属の摩擦挙動に対する温度の影響を明らかにした 論文である. 摩擦係数 $\mu$ の測定は前報の平らなリング
の内径変化率によっている．研究したすべての金属に ついて $120^{\circ} \mathrm{C}$ 以下の温度では $\mu$ はほとんど変わらな いが,この温度近くになると $\mu$ は急増する。はじめに 工具表面に存在する污染膜 (contaminant film) は低 い温度で摩擦挙動に重要な役割を示すが，温度の上昇 とともに除去されて の増大をもたらし，さらに温度 があがれば酸化膜の形成で $\mu$ はあまり増大しない. 高 い温度ではアルミニウム，ステンレス鋼のように温度 の上昇につれて $\mu$ が增大するものと，逆にマグネシ ウム,銅,軟鋼のように減少するものがある。これは形 成された酸化膜のせん断強さの大小による，たとえば 高い温度で，マグネシウムの酸化膜は砕けて粉になり やすく，酸化銅は $600^{\circ} \mathrm{C}$ と $700^{\circ} \mathrm{C}$ の間に遷移点があ り( $\mu$ の減少温度と一致)，また酸化物によっては部 分的融解して $\mu$ を減少させる.このように酸化膜の性 質が演ずる役割は，銅亜鉛合金の亜鉛含有量による酸 化膜の相違や，金属の熱処理が $\mu$ の変化をむたらすこ とによっても確認されている。なお工具の温度や潤滑 剂の温度の影響も検討してある。【葉山益次郎]

\subsection{4}

[736] 安定処理鋼板の塑性流れ [A.N. Bramley \& P.B. Mellor, Int. J. Mech. Sci., 1966, Vol. 8, p. 101〜 114, 図 11, 表 2] 板の垂值異方性に関する巨 視的な塑性理論と，応力・ひずみの実験值を関係ずけ る一連の研究課題の一つとして，4 種の安定処理鋼板 を対象に異方性の程度を調べた論文である。まず実験 では約 $1 \mathrm{~mm}$ 厚の板の引張試験および液玨バルジ試験 を行ない, $\boldsymbol{r}$ 值および $\sigma-\varepsilon$ 曲線を求めている.つぎに Hill の異方性理論にしたがって $r$ 值の式を出し，圧延 方向の加工硬化特性加らそれ直角方向の加工硬化特 性を求める式を出して，先の実験值と比較している. $\boldsymbol{r}$ 值の一致はよいが，異方性材料の加工硬化を塑性仕 事のみの関数としているから，圧延方向およびそれと 直角方向の応力の大小が理論と実験で逆になる鋼板が あり，また板厚方向の応力とひずみについては，異方 性軸に沿った引張負荷の仮定から求めた值とバルジ試 験の結果とはやはり著しく異なっている.しかし $\boldsymbol{r}_{\text {ave }}$ 值から求めたものとはよく一致している。一般の成形 技術における応力比の場合の予見は非常にむずかし W.

[葉山 益次郎]

\section{$539.62: 539.374: 621.892$}

[737] 圧縮変形量に対する摩擦係数の变化 [A.T. Male, J. Inst. Metals, 1966, Vol. 94, p. 121 125, 図 7]圧縮変形過程に拈ける工具と試料間の摩擦係 数 $\mu$ と圧縮変形量との関係を検討した論文である.円 板試料の圧縮に関する Shroeder らの解析を使って $\mu$ を求めると，無潤滑状態で，室温においては，チタ二 ウムで $14 \%$ 程度の圧縮率で固着し， $\alpha$ 黄銅，アルミ 二ウムでは大きな圧縮率 $(30 \%, 37 \%)$ まで $\mu$ は一定 で, 以後前者は急増し, 後者は漸増して変形量の増 大につれて固着する.試料表面に吸収された污染膜 (contaminant film) によって境界摩擦が継続される が，その程度は污染膜の量と大きさによっており，ま た薄い酸化膜が試料表面にそれが広がるのを助けるか どうかに影響される。

潤滑した状態では厚い潤滑膜が形成され，それが破 れるまで $\mu$ の值は変化しないが, それまでの変形量は 